\title{
Electric Vehicle Waves of History: Lessons Learned about Market Deployment of Electric Vehicles
}

\author{
D. J. Santini \\ Argonne National Laboratory 9700 South Cass AvenueArgonne, IL,
} USA

\section{Introduction}

Fundamental trade-offs between gasoline and electric vehicles. In contrast to either the internal or external combustion engine, the fundamental advantage of electric vehicles (EVs) powered by electricity stored on-board in batteries has always been quiet, efficient, emissions free operation. Although emissions do result from fossil fueled generation of electricity, these emissions are removed in both space and time from the point of operation of the EV. High low revolution per minute (rpm) torque, with excellent initial acceleration is another advantage.

The fundamental disadvantage is storage capability. The fuel tank for an internal combustion engine in a "conventional" automobile (CV) can store far more energy, in a much smaller space than a battery pack, at a much lower initial cost. The gasoline vehicle can therefore refuel far more rapidly and travel much further on a single refill. Low top speed relative to gasoline vehicles is also a disadvantage.

An important attribute of electric vehicles is a relatively high peak power capability for short bursts of a few seconds. However, the peak power level tends to be much higher than the sustainable power.

The storage disadvantage of EVs becomes much less important when the vehicles are driven at low average speeds within urban areas. At such speeds, it can take a long time to deplete the battery pack. Further, as average speed declines, the average energy requirement per hour of operation drops off considerably more rapidly than for conventional gasoline and diesel engines, extending the hours that can be driven on a full charge. Unfortunately, at these speeds the fuel saved per hour of operation relative to gasoline and diesel is less than at higher average speeds (Vyas, Santini and Johnson, 2009), and this can require considerably more hours of vehicle use to pay off battery pack costs. Thus, to get the fuel saving per hour of operation up, intensive intra-urban operation of EVs outside of the densest city centers can be more financially attractive (Santini et al, 2011).

\section{Waves of History I: 1890 s through the 1930s}

Personal use electric vehicles. In the United States in the 1890s and early 1900s, EVs competed successfully with gasoline and steam cars predominantly in the Northeastern 
U.S., the most densely developed part of the nation, but also in Chicago. The highest volume manufacturer of EVs at the turn of the century was the Pope Manufacturing Company of Hartford Connecticut (Sulzberger, 2004). New York was then and remains today the most densely developed metropolitan area in the United States. In 1900 the nationwide registration of 4192 vehicles in the U.S. was 1681 steam, 1575 electric and 936 gasoline (Mom, 2004, p. 31). According to Sulzberger, in 1899 electric vehicles outnumbered gasoline by two to one in the major metro areas - New York, Boston, and Chicago. A total of 2370 vehicles were in these three metro areas, so the start of the motor vehicle in the U.S. was clearly in relatively affluent, large major cities. The technological historian G. Mom (2004) indicated that the dollar value of production of electric cars in 1900 was more than half of the total, despite the share of unit volume being $38 \%$. Half of all passenger cars were produced in New England. However, over the next two decades production of motor vehicles in the U.S. moved westward and significantly toward gasoline.

When EVs were in the market from the 1890s to 1920s, they consistently served urbanized areas, rather than rural households and businesses. A caveat, however, is that for the personal EV in the U.S. in about 1914 the share of "home kept" electrics rose as city population dropped, as did the market share of EVs (Mom, 2004, p. 254). A logical deduction is that home kept EV share increased as city density decreased and as the share of single family dwelling units rose. The availability of a parking spot within or beside the electrified dwelling unit was then, and can be expected to be in the future, a major determinant of market success for personal use EVs. Mom concluded that the electric car of 1914 "functioned as the affluent suburban family's second car" (p. 254) having been identified as "an environmentally friendly secondary car" (p. 250). At this time the EV in the U.S. held a share of the market similar to hybrids today $(<3 \%$, far below the turn of the century), but it was a shrinking rather than rising share. Mom also noted that in 1916 the EV was no longer successful in the Northeast - "the electric passenger car seemed to prefer the medium-sized town in the Midwest." (Mom, p. 261). Midwest EVs were supported by "active central stations" that were Electric Vehicle Association of America members. By 1920 the personal use EV was no longer sold in New York, the densest and largest of U.S. cities, with steep hills and long commutes from the suburbs to downtown being blamed (Mom, $\mathrm{p}$ 262).

Vyas, Santini and Johnson (2009) drew attention to the suburban target market for personal use EVs a century later, pointing out that the suburbs of U.S. metropolitan areas are where affluence is greatest, as are the numbers and proportions of garages and multi-vehicle households. Ironically, although the Western U.S. (California) and Northeast have adopted regulations designed to encourage EVs, and the U.S. West Coast is aggressively pursuing electric infrastructure, the largest shares of single family dwelling units are found elsewhere - in the South and Midwest regions (Vyas. Santini and Johnson, p. 60). Typically, regardless of region, about half of all garages and carports are found in suburbs, and half of the households with two or more vehicles are found there. Only about one fifth of either garages or multi-vehicle households are found in center cities (Vyas, Santini and Johnson, p. 61). For the EV market, Santini et al (2011) recently deduced that charging infrastructure costs can be significant, so electric commuting with both house and workplace charging is probably not the least cost market. They therefore examined vehicles not driven to work, on the assumption that the home charger could be used more than once a day. They estimated that only those EVs driven more intensively than average could be financially desirable. Greater affluence is associated with higher annual distance driven. 
Mom concluded that 1910 infrastructure and maintenance costs were an important drawback for the individual household. Despite the fact that "most newly built (italics mine) houses came complete with a connection to the electricity grid" ... the battery and its charging equipment had an important indirect effect" ... pushing ... "purchase and maintenance costs of the electric passenger car far above an acceptable level for middle-class gasoline vehicles." (Mom, pp. 286-287). He also noted that at the time the middle class - the utilitarian user - could only afford one car and therefore could not make a "fleet" choice, purchasing and using both a gasoline and electric vehicle for their respective advantages.

Mom noted that the motorization of areas outside cities was far slower in Europe than in the U.S. The mild success of the personal passenger car EV in the U.S. from about 1905 to 1920 accompanied the wave of gasoline vehicle motorization and regional growth in the Midwestern U.S. Recent investigation of household charging infrastructure cost suggests that installation of suitable charge circuits is far less expensive when designed into new houses than when houses are retrofitted (Santini, 2010). Thus, the growing Midwest would have had the opportunity to install charging infrastructure as it grew and its expanding major cities electrified. Nevertheless, by the early 1920s the personal electric vehicle in the U.S. was rapidly shrinking toward zero production. The counterintuitive computation that Santini et al (2011) made for the 4-5 passenger personal use EV of 2020 was that the rate of utilization (hours of driving) in dense center cities would not be adequate to pay off the added costs of the pure electric vehicle. This is a quantitative candidate explanation for the 1900-1920 failure of the personal-use EV in Europe while it succeeded mildly in the U.S. Congested stop and go driving has financial advantage for the EV only if it is driven many hours per day, such as by a commercial delivery vehicle.

When commercial applications of horses, EVs and gasoline trucks were studied in the U.S. in 1912, it was concluded that horse wagons remained the most cost effective option up to 19 $\mathrm{km}$ per day (Mom, p. 223). If the attainable average speed on the local roadway network in most European nations was then less than about $15 \mathrm{~km} / \mathrm{h}$, and if daily travel for personal activities was between one and one and a half hours, then the implication is that it would have been a financially correct decision at the time for European households to continue to use horses rather than either gasoline or electric vehicles. In reference to first generation electric taxi cab capabilities for Berlin and Cologne in 1907, Mom notes that "first generation taxicabs could go $15 \mathrm{~km} / \mathrm{h}^{\prime \prime}$ which compared unfavorably to the $40-50 \mathrm{~km} / \mathrm{h}$ for gasoline taxis that could only be achieved in practice at night (Mom, p. 142). It was also clear that the speed competition drove up the costs of operating EVs, since a $25 \mathrm{~km} / \mathrm{h}$ top speed required pneumatic, rather than hard tires; a stronger heavier frame; and a larger battery pack to provide needed power. This increased consumption from $220-250 \mathrm{Wh} / \mathrm{km}$ to $350-425$ Wh/ km (Mom pp. 142-143). It was estimated that only larger fleets of taxicabs could afford to own and operate electric vehicles, a finding perfectly consistent with a conclusion that a less intensively used electric vehicle in a household fleet of one would not be economic, as Mom reiterated in his conclusions (p. 291).

The electric passenger car in 1913-14 was far more successful in the United States than in Europe. Mom reports a count of about 1600 electric passenger cars in Europe in 1914, compared to 20,000 in the U.S. Passenger cars were about $56 \%$ of European electric cars and trucks with more than three wheels, while the U.S. share was about $67 \%$ (Mom, p. 252).

Although the peak number of electric passenger cars produced in the U.S. in 1915, at 4,715 (Mom, p. 254), was well in excess of the production of 1900, at 1575 (Mom, p. 31), and can be 
called a success, the sales of 611,695 gasoline cars in the first nine months of 1915 (Mom, p. 283) was an overwhelmingly greater increase relative to the 936 gasoline cars produced in 1900 (Mom, p. 31). At this point, 43\% of gasoline vehicles were sold with an electric starter, which had been introduced in 1912. According to Mom, "it is not correct to claim that the electric starter motor meant the deathblow for the electric car. But it did mean the last nail in its coffin" (Mom, p. 283).

In the U.S., the Ford Model T (initiated in 1908), which did not adopt an electric starter, had accounted for more than half of total vehicle sales during most of its lifetime. However, during the early 1920s its market share began to erode as more powerful cars with electric starters gained market share at its expense. The " $\mathrm{T}$ " had also been designed for low speed operation on poor dirt roads, having large diameter wheels and a high ground clearance. The 1920s saw increasing adoption of gasoline taxes to support state road building (Majahan and Peterson). The needs of the electric vehicle for reliable tires with low rolling resistance had led to development of the bias ply tire, a technology that was then adapted for use by gasoline vehicles in 1915 (Mom, p. 260). As noted by Loeb (1995), the electric starter, which itself had been developed for hybrids (Mom, p. 282) allowed reliable starting of engines with power well in excess of that of the $15 \mathrm{~kW}$ Model T. The electric starter ultimately allowed higher cranking power than a human arm could provide, allowing reliable starting of an engine with a much higher compression ratio, which in turn enabled more efficient gasoline engines, once octane enhancers had been added to gasoline (Loeb, 1995). The higher average speeds attainable by gasoline vehicles with more powerful engines, good roads, better tires and reduced ground clearance (thus reducing aerodynamic drag) most likely played a role in the 1920s demise of the personal electric vehicle, whose sustainable top speed was inherently limited.

The widespread 1912-16 adaptation of a cost effective combination of electrical and mechanical features in the predominantly mechanical gasoline vehicle signaled the end of the electric passenger car about a decade later. While attempts to combine electric and mechanical drive in hybrids failed in the marketplace, about a century later the new question is whether an increase in electrification of the gasoline vehicle, in the form of hybrids and the plug-in hybrid will again keep the market potential of the pure electric vehicle to less than $3 \%$ of the U.S. and European markets in coming decades. Mom, quotes a vice president for research from Ford in his closing pages, saying that "the most costeffective and efficient road to a greener world is through the gradual electrification of vehicles ... rather than switching to an all-electric powertrain."(Mom, p. 299). Mom praises the electric car for pressuring the gasoline vehicle to adapt and be better, advocating exploration of alternative powertrains. However, he does not quote a contrary opinion from another auto executive advocating the desirability of a technological jump to the all-electric powertrain.

Trucks and taxis. The demise of the personal use EV did not mean the demise of the EV. Mom demonstrates that commercial trucks, and industrial (non-road) trucks continued to grow in use during most or all of the 1920s and in some applications on into the 1930s. The electric taxi was abandoned mid-1920s-decade. From the early 1900s, growth rates for commercial trucks in New York and Chicago were dramatic (Mom, pp. 211, 228) and considerably faster than for passenger cars. The pattern had a similarity to that of the personal use vehicle. Motorization of services that had been provided largely by horse wagons and horse driven taxis was generally rapid, so that absolute totals of both electrics and gasoline business vehicles grew rapidly. The share of the motorized services held by 
electricity was considerably higher than in personal use vehicles - "a quarter of the entire American truck fleet" in 1912. In 1914 a quarter of all U.S. electric trucks were in New York City, and those represented 39 percent of New York's fleet of motorized trucks (Mom, p. 228).

In general, this was accomplished by much greater utilization of the electric vehicles and the battery packs in the business vehicles than was the case for personal use vehicles. Many of the business fleets in both the U.S. and Europe used battery swapping, with more than one battery pack per vehicle (Mom, p. 94, 231). The importance of assuring intensive use via reliable operation, with low maintenance, led to expenditures on well trained battery maintenance staff and also more expensive, more reliable batteries in commercial applications. Mom said that "for the electric car owner ... the character of the lead battery formed a virtually insurmountable barrier ... looking after the battery ... really needed the constant attention of a physician and a trained nurse." (Mom, p. 287). As of about 1911, commercial fleets found the "tubular lead and Edison batteries to reduce maintenance, though at a much higher cost. The commercial vehicle fleets made intensive enough use of their batteries to make this trade-off pay off. A private owner could not (Mom. P. 288). This shows the potential problem of mistranslating good reliability in fleet applications to an argument that a technology will also be reliable in the hands of an individual consumer.

Commercial fleets frequently charged battery packs overnight, very often at much lower cost per kWh than for daytime charging. With battery swapping, a 24 hour operation could be implemented with overnight charging and maintenance and checking on one battery when out of the vehicle while the other battery was in use. With swaps made in a matter of minutes, it also allowed the vehicle to stay in service for many hours of operation per day, rather than slowly recharging during the day. This significantly increased fuel saving per vehicle per day, helping pay off the investment.

Even so, the key to economic viability was to find the appropriate field of application. A 1924 book on the merits of the electric truck was written by E.E. La Schum of the American Railway Express Company. In this book La Schum was effusive in his praise for the electric truck, "the speediest of trucks where stops or delivery are frequent and traffic congested." (Mom, p. 245). He predicted that electric trucks, which then were used in a normal range of $48 \mathrm{~km}$ (perhaps about $7 \mathrm{~km} / \mathrm{h}$ for an 8 hour workday, less if the truck were used on two or more shifts with battery swapping) would increase their competitive daily range to $64 \mathrm{~km}$ and more. At the time the American Railway Express Company had 1225 electric trucks, 575 other electric vehicles, 8200 horse wagons, and 2,500 gasoline trucks. The superior average speed of the electric truck, when stops were involved, probably included an advantage of a quicker start once the driver returned to the truck, in part because the electric did not have to be put into gear with a manual transmission, nor shifted. If the competing gasoline truck were turned off at stops in order to save fuel, this would also slow the start-up process upon return to the truck.

Santini et al (2011) recently estimated that financial viability of hypothetical 2020 mass market pure electric passenger cars with from 120-160 km of range would require full depletion of the pack and some recharging during the day under recent U.S. average gasoline prices and electricity rates. Typical passenger cars would not be driven enough to cause full depletion of such an EV. Only those driven far more hours per day than average could fully deplete the pack on a normal day, enabling additional gasoline saving via a daily recharge. Santini et al note that such vehicles are far more likely to be driven in suburbs than center cities. Identical electrical rates of $\$ 0.10$ per $\mathrm{kWh}$ were assumed for both nighttime and 
daytime charging. However, the goal of the U.S. Federal Energy Regulatory Commission is to enable and encourage implementation of time-of-day pricing in the U.S. This will increase summertime average daytime electric rates to above $\$ 0.20 / \mathrm{kWh}$, but will lower overnight rates by only a few dollar cents. Should time of day rates become common, second charges during the day might actually lead to higher energy costs per mile for the second charge than if a full hybrid gasoline vehicle were used.

High daytime electric rates were a problem in the past. Mom noted that public garages that had to return fully charged vehicles to customers suffered when the customer demanded delivery "during expensive peak hours" (Mom, p. 217). In fact, utilities (central stations in Mom's terminology), under the guidance of Samuel Insull, chose to offer "multistep" rates to stimulate charging overnight charging between $10 \mathrm{pm}$ and $7 \mathrm{am}$. Today's term is "offpeak" or "time-of-day" rates. The truck was preferred as a customer over the passenger car because the "truck used 400 to 933 times more energy than a light bulb" while the car "consumed only 107 times more energy" (Mom, p. 208). In part, this difference was due to the greater hours per day of operation of the truck, not only the greater vehicle mass.

Mom found that electric vehicles serving business were consistently found in fleets of much larger size than were gasoline vehicles (Mom, p. 246). These fleets found it necessary to hire "competent men to take care of the batteries" (Mom, 229; see also p. 216). Costly maintenance made it imperative to spread the maintenance expertise costs over a number of vehicles. The idea of implementing battery rental services that thereby spread the cost of maintenance over a large number of vehicles of several different owners was tried in the "Hartford system" set up in 1910 (Mom, p. 230). This system, which involved a fixed fee and a mileage charge, with battery pack exchange using packs charged overnight, was implemented in many cities by 1916, though only hundreds of vehicles were involved. Battery pack exchange was also common in taxi fleets in Europe, though this was implemented by the taxi fleet itself, not as a rental service such as the Hartford system.

Another cost that promoted larger fleets was the per vehicle infrastructure cost involved in setting up in-house charging facilities for relatively few vehicles. However, if the infrastructure costs could be paid, a large fleet could then get a discounted electricity price. At "a purchase of $50 \mathrm{~kW}$ or more and a garaged fleet of 75 to 150 electric cars", Commonwealth Edison of Chicago offered a rate of $\$ 0.02 / \mathrm{kWh}$ (Mom, p 254).

In Detroit in 1914 a taxi company tried the innovation of "curb boosting" - recharging of taxis while waiting at taxi stands. This idea was also implemented in Chicago and St. Louis in 1917, but it involved considerably fewer vehicles than the Hartford battery rental system and did not become common practice. Daytime rates for electricity may have been a deterrent.

Britain came late to the electric delivery truck, but found the very successful market niche low speed urban delivery with many stops. In particular, milk trucks, which made quiet, clean early morning deliveries, became electrified in large numbers. Growth was dramatic from 1934 through 1949, by which time nearly 20,000 electric trucks were in service (Mom, p. 268).

Today, it is recognized that a portfolio of powertrain technologies is likely to be necessary in coming decades, as nations of the world slowly switch transportation from oil to other fuels. In effect, this process took place from 1895-1945 as nations switched from the grain fed horse and from the coal fed iron horse (steam locomotive) to the automobile. The electric passenger car and truck competed against horse drawn vehicles to a much greater extent than it competed with the iron horse, which dominated intercity travel. For commercial 
trucking services, a careful, but optimistic assessment was made by researchers from the Massachusetts Institute of Technology, indicating that the electric truck was more costly than horse drawn wagons at short distances up to $19 \mathrm{~km}$, but less costly than a gasoline truck up to its maximum range of $72 \mathrm{~km}$ (Mom, p. 223). The study optimism criticized by Mom involved an assumption of a cost of electricity only available to large fleets served by large central stations supportive of electric drive. The key point here is that the electric vehicle did not supplant the current technology - horse wagons - when delivery wagons were used in short daily distances.

Mom, discussing the 1915 time period, said that "only after the electric vehicle had broken the most ardent resistance of the horse economy could the gasoline rival invade the city" (p. 293) and "the gasoline car even stole the entire city car concept" (p. 298). The position here is that this is an overstatement at the least, and perhaps simply incorrect. The personal electric car did not work in dense urban environments with multi-family rental housing units, where short distances to needed services made the electric vehicle far more expensive than walking, the horse taxi, or other public transportation. The American Railway Express Company - a company that very carefully evaluated the most viable applications of electricity to its fleet and adopted electricity with enthusiasm - retained more horse wagons than gasoline and electric trucks combined in 1924. Thus, it seems dubious to assert that the horse economy had been broken in 1915, much less by 1924, when the personal electric passenger car - which apparently never succeeded in large dense center cities - was no longer available. It would appear that the horse economy was probably fully broken later by the gasoline vehicle, well after the horse economy had held its own against the electric vehicle.

This interpretation of the past is identical to the conclusion that Santini et al (2011) reached with regard to the probable status of the hypothetical electric passenger car of 2020. The less expensive existing technology - gasoline in the 2020 case - is financially superior in the event of a low daily utilization rate. Accordingly, the financially viable four-five passenger electric car of 2020 was found to be a heavily utilized suburban vehicle, not a "city car", contrary to recent graphics generated by several automakers (Berretta, 2009; Satyapal and Aceves, 2009; Suckow, 2009; Yokoyama, 2009). The fact that the personal use electric passenger car failed earlier in New York City than elsewhere in the U.S. was not a coincidence. That Mom concluded that the personal use electric vehicle was a second car for the urban affluent also was not a coincidence.

In Europe, electrification of taxi fleets was often promoted by municipalities via regulation, so financial viability was not the only criterion. The regulations were adopted in order to prevent the noisy and smelly gasoline vehicle from capturing the downtown urban market. Although Mom did not associate the city regulations with preferences of affluent customers, it seems likely that relatively affluent business leaders had a strong influence on these decisions. Taxis were more likely the for-fee transportation service chosen by the urban affluent, while the typical urban resident most likely used trolleys and wagons (Omnibuses). Generally speaking, the downtowns of the largest metro areas within a nation are habited on a business day by some of the nation's most affluent citizens. New York City certainly falls into this category within the United States. Thus, to the extent that the electric truck and electric taxi were chosen instead of horse taxis and wagons, and instead of gasoline taxis and trucks, there was most likely a relationship to the preferences of the affluent for better hygiene (vs. horse taxis and wagons) and quieter operation (vs. gasoline taxis and trucks). Reduction of odor was probably a goal in both cases. 
Mom called the commercial truck competition the "decisive battle", emphasizing that it was fought in the city. Advantages for particular niches were: "easy speed control (sweeping and sprinkling trucks), trouble free stop-start operations (door-to-door delivery, garbage trucks), absence of smell and noise (ambulances, transportation of food supplies)" (Mom, p. 285). To the smell and noise list taxis may be added. This decisive battle was largely (though not completely) lost by the 1930s. The gasoline vehicle improved so dramatically in the 192535 period (Naul, 1978; Naul, 1980) that it eclipsed both the horse and the electric vehicle, which will be discussed below.

Thus, the hypothesis is that the positive environmental features of the electric vehicle accounted for its limited success among the well-educated affluent in leading industrialized nations from 1895-1935, but its expense and other shortcomings prevented it from ever becoming a standard vehicle serving the majority of the population. Mom noted that many electric vehicle advocates thought that a part of the problem was behavioral - that consumers who did not purchase electrics were unwise, uneducated, or perhaps uncivilized. An alternative hypothesis is that the market worked well and there were very sound reasons, based on fundamental financial and systems engineering principles and perfectly reasonable consumer preferences, which accounted for the degrees of success and failure exhibited by electric drive.

\section{Causes of Success or Failure}

This examination and interpretation of the first waves of limited success for the electric vehicle hints that a study of history tells us that the past problems of electric vehicles are fundamental, and implies there is a significant risk that history will repeat itself and the pure electric vehicle will not represent a significant competitor to adapting gasoline or diesel passenger vehicles and trucks. However, it is important to concede that there are some significant differences in the present, so the outcome may not be the same.

For interpretation of this discussion, it is useful to summarize the three vehicle failure vs. success factors identified broadly by A. Loeb in 1995, and in more detail by Mom in $2004-$ (1) power, (2) energy storage, and (3) adequacy of infrastructure. In the case of infrastructure, multiple types of infrastructure-related constraints were discussed by Mom roads, electricity, water (with reference to the failure of steam cars), maintenance, refueling methods (exchange charging systems for business vehicles), safety of interacting modes operating at different speeds, flexibility of destination options.

By the 1920s, the electric passenger car was relegated to being marketed as a "lady's car" for the affluent. "It was called a lady's car' it was said it wouldn't run up hills; it was said it couldn't go fast enough ... I would ride in an electric car if it were not for the fact that all my neighbors coming to the city pass me with their gasoline machines." (Mom, pp. 280-281).

Within the section on limited energy content, Mom paraphrased the 1928 statements of an executive of Accumalatorenfabrik AG, a German battery manufacturing company that had existed since 1887 -" the electric car fell into disuse for private purposes, because it presented problems when one wanted to use it as a touring car." (Mom, p. 288). For a 1914 $400 \mathrm{~km}$ publicity run between Boston and New York, the "aerodynamic runabout" Bailey Roadster spent almost half of the 23 hours in five "boosts", implying recharging at about 80 $\mathrm{km}$ intervals. In the same paragraph it is stated that the manufacturer claimed that the Bailey had a range between 130 and $190 \mathrm{~km}$ (Mom, p. 256). This highlights the problem of electrics for intercity travel - such travel results in highest electricity consumption per km 
and lowest range, and a need to recharge frequently at a time when vehicle occupants place a high premium on average speed to destination (Santini, 2010).

Gasoline vs. Electric Vehicle Supporting Infrastructure. With the exception of the detailed explanations of Mom, historians generally regard range and cost as the primary reason that EVs failed, while CVs succeeded. However, A.P. Loeb (1995) also emphasized the absence of fueling infrastructure for the EV, vs. presence of supporting infrastructure for the gasoline powered vehicle, as an unrecognized cause of a very rapid U.S. expansion of gasoline fueled vehicles by 1904. In 1900, there were 4192 vehicles registered in the U.S. (Sulzberger, 2004). In 1905, there were 78000 (Melaina, 2007). The vast majority were fueled by gasoline. Loeb (1995) stated that the "issue was settled by 1904-5". Mom does not quantify electricity availability constraints until one is far into his book. He notes that in 1917 " 7 million of the 22 million houses in the United States were connected to an electricity grid" (Mom, p. 233). Loeb noted that the rapid expansion from 1901 to 1904 was largely due to sales of the twopassenger, single cylinder gasoline fueled Oldsmobile. This important "take-off" of the gasoline vehicle in the U.S., well before the singularly successful Model T (1908) and the electric starter (1912) were introduced, is not mentioned by Mom.

As noted earlier, the year 1900 concentration of steamers within Boston, New York and Chicago was even greater than for electrics. Although also capable of using widely available petroleum products, steam cars proved to be limited in range and overall average speed by the availability of water. Winter temperatures below freezing were clearly problematic, as was high mineral content in the Midwest (Mom, p. 291). Sulzberger (2004) reports that the range of an early steam car, before requiring replenishment of water, was 25-30 miles, no more than an electric vehicle of the time. The development of condensers to allow reuse of water and a range of 150 miles were implemented too late - in the 1920s - and added cost.

Loeb credits superb road infrastructure in France for early emergence of automobiles there. Mom noted that the improving roadway infrastructure in the U.S. appeared to be an enabling technology for expanding truck services (heavier vehicles than passenger cars) in the 1920s, while the previously existing roadway infrastructure had been adequate for well adapted light passenger cars. "A direct relation could be demonstrated between the number of trucks and the length of the paved roads in cities with more than 30,000 inhabitants." (Mom, p. 238). Although the improved U.S. roads were clearly not necessary for success of light gasoline passenger cars (the Model $\mathrm{T}$ in particular), they were probably sufficient (along with other developments) to help cause the demise of the electric passenger car. Majahan and Peterson (1985) examine the diffusion of the state gasoline tax in the United States, showing that it swept the nation in the 1920s. It seems doubtful that business truck interests alone could account for this sweeping support of improved roads. Thus, private vehicle users must have seen a benefit. I presume that the benefit was higher speed and greater reliability (reduced tire failures). The practical realization of the benefits of dramatic increase of power and top speed of gasoline vehicles from the mid-1920s to mid-1930s (Naul, 1978, 1980) - unmatched by electrics - was undoubtedly enabled as a practical matter by the improved roads that were built in the 1920s.

Over a decade after Loeb's examination of the role of gasoline infrastructure, Melaina (2007) provided more extensive details of early gasoline refueling infrastructure. He asserts that "a key issue during early phases of infrastructure development is the requirement to provide a fuel inexpensively and in small volumes from many locations dispersed across large geographic regions." Melaina shows clearly that gasoline was a relatively simple add-on to 
an extensive delivery infrastructure for kerosene. "100 refineries and vast networks of bulk storage facilities and tank wagons" existed. In 1906 Standard Oil operated 3573 bulk stations, receiving barrels and tank wagon loads, distributing refined products (mostly kerosene) locally. Gasoline, used as a solvent, was widely available to both urban and rural populations before the automobile. Gasoline was in excess supply, effectively a waste product, often dumped into nearby rivers.

That the electric vehicle market could not have grown as rapidly as gasoline vehicles in a largely rural nation should not be surprising. In 1907 less than 10\% of households had electricity (U.S. Department of Commerce, 1975). Another problem of the time was that the competition between AC and DC electricity had not yet been resolved, making national standardization of charging infrastructure very unlikely. Perhaps the fear of electrocution, used by Edison to promote continued use of DC electricity instead of the ultimate switch to AC played a role in the reluctance of individuals to assume the risk of field repairs of a malfunctioning electric vehicle, while familiarity with powered steam farm equipment made the gasoline vehicle transition seem more manageable. The war of the currents was underway during the 1890s and was not settled until after the turn of the century (Wikipedia, 2011).

Melaina's infrastructure requirements for successful introduction are encouraging for implementation of electric drive over 100 years from the first attempt. Nearly $100 \%$ of households in Europe and the U.S. now have electricity. The distribution system cannot deliver energy to electric vehicles at anywhere near the rate of gasoline, but small amounts can be delivered over several hours, at the dwelling unit, in the same way that cans of gasoline were originally stored at the house to fuel early gasoline cars. Because of the advent of air conditioning, afternoon summertime cooling requirements in the U.S. have led to construction of many very efficient combined cycle natural gas power plants which sit idle overnight and in off seasons.

Technological developments in drilling technology have only recently led to significant increases in estimates of the proven reserves of U.S. natural gas, and great optimism about its potential elsewhere. Thus, as gasoline was in excess in 1900, U.S natural gas producers, along with utilities that own natural gas powerplants, are looking for new customers. Further, a movement toward the "smart" grid, with time of day rates encouraging use of electricity overnight via reduced price, can encourage electric vehicle use, although the required metering is not inexpensive. In any case, it is clear that for plug-in electric drive today, initial infrastructure is not the limiting factor it was in 1900.

Melaina observed that the emergence of the refueling station followed the emergence of the gasoline car by a couple of decades. He noted that "non-station refueling methods allowed vehicles to be mass-produced without sales being inhibited by consumer concerns over limited refueling availability" (Melaina, 2007, p. 4922). Cans, barrels, and home refueling pumps emerged concurrently with gasoline vehicles. Next came refueling at repair shops and curbside dispensers (both will be used to support EVs). The ability to "fast fuel" many vehicles at a location dedicated to refueling followed in 1915-24, long after the vehicles.

The working assumption at this time, however, is that electric vehicles must have a network of public charging stations in place before electric vehicles are to be sold, if electric vehicles are to be successfully introduced into the market. The Electrification Coalition (2009) contends that the minimum number of public chargers per electric vehicle to be 1.5 in 2010, 1.0 in 2020, and 0.5 in 2030. In Germany in 1914, there were 862 passenger EVs, 554 electric trucks, 270 commercial-and-mail three-wheeler EVs, and 3 private 3-wheeler EVs. There 
were 39 charging stations, 13 for taxis only, 13 for mail vans, and 11 for private car owners (Mom, p. 252). In other words, there were 11 passenger car charging stations for 862 passenger cars, which is 0.013 stations per car.

Powertrain vs. Vehicle Body Technology. Study of the nature of the evolution of early gasoline automobiles illustrates rapid technological development which has an analogy for recent (and anticipated) battery chemistry developments. While the need for specific energy in batteries is well known, and was not a problem for gasoline powertrains in the late 1800s, specific power was indeed a problem. Presnell (1992) clearly illustrates the importance of rapid improvements in specific power for gasoline engines in Europe. The power from the original Benz car of 1885 to its volume production version jumped from "an estimated 1/5 $\mathrm{kW}$ to around $2 \mathrm{kW"}$ ", from a single cylinder engine and with a maximum speed of $19 \mathrm{~km} / \mathrm{h}$. Light vehicle weight was initially necessary - the engine was mounted in a "tricycle". By 1899 Daimler - the first to produce a purpose built automotive engine - had developed a $18 \mathrm{~kW} 4$ cylinder racer good for over $80 \mathrm{~km} / \mathrm{h}$. The Daimler automotive engine was one sixth the weight of a representative conventional stationary Otto four stroke engine of 1886.

De Dion-Bouton in France also started with a modest engine $-1 / 2 \mathrm{hp}$ mounted in a tricycle, soon switching to four wheels with a single cylinder engine design rated at $2.5 \mathrm{~kW}$ by 1900 , and $6 \mathrm{~kW}$ in 1905 (Presnell pp. 12,14). This engine type provided the foundation for the early French automotive industry, being used in "a hundred different makes of vehicle in the 1898-1908 period and launched many a respected marque", among them Renault (Pressnell, p. 12).

The single cylinder engine in a small vehicle was also the starting point for sales of thousands of vehicles from a single manufacturer in the U.S. The curved dash, single bench seat Oldsmobile was "a clever exercise in minimal motoring" with "long springs giving a comfortable ride on poor roads", with a "chug along" engine limited to $500 \mathrm{rpm}$ (Presnell). The 1901 version of the Oldsmobile is reported by General Motors to have a $4 \mathrm{~kW}$ engine, increasing to $5 \mathrm{~kW}$ in the 1904 model (Generations of GM History: Heritage Center, 2011).

Loeb emphasized the importance of consumer reaction to increasing power and speed in the early phase of the development of the automobile in the U.S., followed by ascension of the automotive virtue of utility realized in the Model T Ford. The desire for cost-effective mobility had been demonstrated by the Oldsmobile success. On both sides of the Atlantic, the power density of Otto cycle engines jumped in the 1890s, then leveled off in a mass produced engine design that was the foundation for production of tens of thousands of vehicles. Where France's start was via mass production of a De Dion-Bouton single cylinder engine used by many vehicle manufacturers, Ford took this a step further and mass produced the whole vehicle, providing affordable and reliable automotive transportation to the middle class (Loeb, p. 75). The Ford Model T engine produced $15 \mathrm{~kW}$. With two bench seats, this mass market car seated four or more people. The Model T weighed $544 \mathrm{~kg}$, the single bench seat Oldsmobile 318. The Model T engine had four cylinders and 2.9 liters of displacement, while the prior Oldsmobile had a single cylinder engine with 1.6 liters of displacement (Vivian, 1994). The Model T engine power rating was unchanged throughout its nearly two decade lifetime, according to Naul (1978).

Sulzberger stated that lead acid batteries of the time had to have $76 \mathrm{~kg} / \mathrm{kW}$. The 1897 Pope Columbia Electric Phaeton Mark III weighed $816.5 \mathrm{~kg}$, 386 of which was battery. If the battery had achieved the best performance cited by Sulzberger, this would give $6.2 \mathrm{~W}$ per kilogram of vehicle weight. The Ford Model $\mathrm{T}$ had more than four times more $\mathrm{kW} / \mathrm{kg}$. Further, since the battery power number is likely a peak power rating, it is likely that the relationship of continuous power per $\mathrm{kg}$ was even more favorable toward the Model $\mathrm{T}$. 
Thomas Edison spent millions of dollars and years to develop better batteries, but, despite considerable improvement, increased cost was a problem too great to overcome for personal automotive use.

The significant and rapid rise of specific power of Otto cycle engines in the 1890s was a key enabler of the initial success of the gasoline engine. More than two decades later, from 1926 to 1935 the power of a base model Ford went from 20 to 95 . There were similar, though less pronounced increases across all models (Naul, 1978, 1980). This second jump in engine power was undeniably a key cause of the final demise of the personal electric vehicle and taxi, and later the commercial truck.

Today, the next wave of EVs is benefiting from a shift in battery chemistry to lithium-ion (liion), a chemistry that not only provides higher specific energy; it also can provide considerably higher specific power (Kalheimer et al, 2007) - nearly an order of magnitude more gravimetric specific power than the present $\mathrm{NiMH}$ battery chemistry in some circumstances. Dramatic improvement in performance capabilities of engines gave the gasoline vehicle its early foothold in small vehicles capable of carrying one or two passengers. A possible historical analogy is that an enthusiastic base of consumers finding the improved performance made possible by li-ion batteries has provided one anchor for the modern EV technology. The two-seat Tesla Roadster and BMW Mini EVs have been received relatively enthusiastically by those who drive them. Based in large part on reactions by drivers in its Mini EV tests, BMW is proceeding with multiple EV designs in four passenger vehicles, one of which will use lightweight composites and aluminum - a significant redesign of the vehicle body comparable to what Tesla has done with the Roadster. Tesla is also putting into production a five-plus-two passenger sedan, the Model $\mathrm{S}$, with a stamped aluminum body rather than composites. Neither manufacturer is seeking a middle class market, but both do intend to produce "family sized" vehicles for performance oriented higher income consumers.

The early mass market success of the gasoline engine occurred when the technology reached an acceptable plateau of capability that could be made available to middle income consumers via the cost reducing benefits of mass production. The De Dion-Bouton and Model $\mathrm{T}$ engines were produced in very large volumes, enabling cost reductions that in turn enabled vehicle pricing resulting in high volume sales. Nevertheless, these engines initially had to appeal to small markets, before mass production was achieved.

For its hybrid vehicle design, the long-term possibility of profits at high volume (realized after several years) with reasonable cost was seen by Toyota in the early 1990s. Electric drive has today obtained a foothold in the heart of the automotive market because of this longterm vision. The NiMH battery may not have been adequate for EV success, but it did allow the technology innovation of packaging of electric and conventional mechanical drive together in hybrids that has created the current general confidence in electric drive. In retrospect, no manufacturer in the 1990s was willing to gamble that the Nickel Metal Hydride battery chemistry would lead to levels of EV cost and performance that could result in mass market success.

Lesson: mass market success of an alternative powertrain requires a technological leap in capability, initially supporting low volume sales to innovators and early adopters (most of them reasonably affluent), leading to mass production and cost reductions for its most critical components, making the technology affordable.

Judgments of participants interviewed for the IEA HEV\&EV Implementing Agreement's Lessons Learned in Market Deployments of Hybrid and Electric Vehicles study was that 
production in many tens of thousands - perhaps triple digits - is necessary for batteries to be cheap enough to allow EVs to be mass marketed. Predictions of cost reductions as a function of production volume by Kromer and Heywood (2007) and by Santini, Gallagher, and Nelson (2010) for lithium ion based battery chemistries are quantitatively consistent with these opinions. Nissan is taking the gamble that high volume production of lithium ion based battery packs will reduce costs adequately. In contrast to the choices of Tesla and BMW regarding lightweight body materials, Nissan is relying on a conventional steel body to keep costs low. The gamble is "Ford" like in the sense that Nissan is the only manufacturer committed to production and sale of one model of electric vehicle within the leading sales size class in the world. Nissan follows Toyota's example, adopting significant corporate ownership of production of battery packs for the vehicle. Both the powertrain/storage system and vehicle body are to be produced in much higher volume than any other manufacturer has presently committed to.

One question for the gasoline vehicle of the early 1900s is what might have happened had the specific power of engines not increased to the levels that made the four-plus-passenger Model $\mathrm{T}$ and numerous French body alternatives on standardized De Dion-Bouton engines possible? Would steam or electric powertrains have succeeded, or would the horse have held its large share of the market? It can be argued that attributes such as specific power and specific energy of the powertrain and fuel storage device(s) dictate the approach that must be taken with the rest of the vehicle body. Looking back at the start of the gasoline vehicle from 1885-1900, the EV-related efforts of Swiss manufacturers in the 1990s look similar, but success did not follow. Swiss EVs were small, lightweight, low speed, low acceleration vehicles to enable adequate range and performance. An emphasis was placed on light weight. Many experiments, with multiple battery chemistries, were tried. No successful standard model emerged. The Mendrisio experiment found that the majority of consumers chose a single vehicle type (Peugeot 106) from the established vehicle manufacturer that provided the best service. Among vehicle manufacturers interviewed in the IEA HEV \& EV Implementing Agreement's “Lessons Learned" study, Peugeot had made the biggest commitment to volume production in the 1990s, building a factory capable of producing 20,000 vehicles. Yet this commitment, seen to lead to the most success among Mendrisio participants, was not adequate, given consumer response to the vehicle capabilities and costs. Only thousands of Peugeot electrics were sold in the best year.

Multiple participants in the "Lessons Learned" study have said that changes in consumer behavior are necessary if EVs are to succeed. Mom shows that such thinking by electric vehicle proponents was also common in the early 1900s - the EV advocates attempting to convince potential customers that lower performance was a desirable attribute. Toyota participants expressed the opinion that consumer preferences would have to change, and a Swiss consultant argued that a change to a "future oriented attitude" was necessary. It is clear that over a century's time households (and entire economies) did adapt their behavior to the features of the gasoline vehicle. However, the question is one of cause. Did the vehicle entice a change in behavior, or did consumer behavior shifts enable the vehicle to succeed? The former direction of cause seems more plausible. Mom saw the gasoline automobile "culture" as one that was imposed on all other modes of travel, pushing them aside in favor of the needs of the gasoline automobile. "The building of an automobile only highway network was forced on the users ... the highly functional flexibility ... led to the collapse of one of the densest regional tramway systems in the world." (Mom, p. 296). 
Lessons: Batteries - even lithium ion - are inadequate to allow consumers to purchase EVs without adapting their behavior. Since large changes in behavior are unlikely in a short period of time, EV designs must provide a large fraction of the mobility provided by the competing means of travel. If an EV design competes with a small volume gasoline vehicle type (such as a two seat passenger car), it will not gain a large share of the national market even if it is successful against its competition.

A fundamental question is whether the powertrain/storage system dictates the vehicle body, or does the vehicle body dictate the powertrain/storage system? For the Nickel Metal Hydride (NiMH) chemisty, the Toyota Prius, quite conventional in many respects, adapted the vehicle body a bit, and the powertrain/storage system a lot, and captured half of the market for hybrid powertrains in the U.S. The Prius designers did choose to avoid too much weight and cost in the sense that the battery was made as small as possible and no plug-in feature was attempted. In this case, the relatively advanced battery design was adapted to rigid short term consumer expectations and behavior, assuming that only slight changes in the vehicle body would be accepted. Mom saw the success of the gasoline powertrain as one of successful adaptation first, using existing coachwork, roadways and fueling infrastructure. This led to the lowest cost among the competing powertrains during the takeoff phase, only later leading to establishment of redesigned coachwork, roads and fueling infrastructure.

To allow batteries available to succeed in an electric vehicle in the 1990s, GM chose to develop an entirely new 2 seat body design that would hopefully provide an enticing combination of performance attributes - even with lead acid batteries. Here the attempt was to spend money on the body in order to make the initially inexpensive, proven battery chemistry workable. This body and battery package was very popular with very few consumers. The limitations of the batteries required plastic and aluminum rather than the steel used in the Prius body, and a body shape achieving a coefficient of drag of 0.19, well below the 0.26 value for a Prius. With far less financial resources, multiple Swiss innovators also attempted to develop an entirely new vehicle body configuration, emphasizing very light weight to enable lead acid, nickel cadmium, and sodium sulfur batteries to provide adequate performance to meet relatively inflexible consumer expectations. Neither GM nor the Swiss were able to achieve sales rates that promised reaching production volumes necessary to succeed. They had in common an initial attempt to succeed in a very small market niche - a smaller than average utilitarian vehicle with conventional (or worse) range and top speed in comparison competing gasoline vehicles. Recognizable power fade as the battery depleted was an issue.

Attempting to take advantage of the greater specific energy and power of li-ion more than a decade later, the $\$ 100,000+$ Tesla roadster EV designers sought a different two-seat vehicle niche market - the high cost, high performance segment. Tesla engineers recognized there was still a need for a very lightweight body. Aluminum and carbon fiber are used for light weight, with a few parts common to the Lotus Elise, a lightweight sports car that uses a similar aluminum frame, but does not use carbon fiber body panels (Siry, 2008). Performance and range well beyond that of an EV1 were demonstrated in a two seat vehicle. The much less expensive (than the Roadster) base version of the coming Tesla Model $S$ sedan will use a less expensive aluminum body. Though slower and with less range than the Roadster, it will accelerate faster and achieve greater range than an EV1, and be capable of seating 5 adults and two children, but its price is to be more than $\$ 20,000$ more than the EV1's nominal $\$ 33,000$ price (EV1's were leased, not sold). 
A study of the design of the EV1 and the Chevrolet Volt demonstrates a lot of commonality in component placement and configuration. Acceleration capability is no longer the primary selling point, and the vehicle has four seats, more suitable for the middle class market. Nevertheless, a gasoline engine is included because of concerns over charging infrastructure. While prices of Prius HEVs are within the reach of the U.S. middle class, the Volt, produced in tens of thousands, at a base list price double that of the Prius, is not. The Nissan Leaf, to be produced in hundreds of thousands uses a conventional steel body. It is priced below the level of the Volt, but still expensive relative to a conventional gasoline vehicle of the same size, and compared to the Prius. U.S. subsidies of $\$ 7500$ per vehicle will help, but battery costs must come down (or oil and gasoline prices rise) for high volume cost competitiveness in the U.S. market.

Estimates of 2020 costs of an electric vehicle similar to the Leaf, produced at volumes of 100,000 per year, are for a "generic" advanced lithium ion battery pack cost of $\$ 9340,27 \%$ of the estimated $\$ 34845$ first cost of the vehicle and its supporting infrastructure (derived from estimates based on simulations supporting Santini et al, 2011 [vehicle] and Santini, Gallagher and Nelson, 2010 [li-ion battery pack]). La Schum quoted cost of an electric truck in his 1924 book as $\$ 3030$ without the battery, and $\$ 970$ on average for the battery (Mom, p. 245). The share of battery cost then was $24 \%$, less than the above estimate for 2020 . Thus, the generic issue of high capital cost for batteries remains a problem nearly a century later. Limited range and limited top speed relative to the competitive gasoline vehicle also remain a potential problem, though top speed appears to be much closer to that for gasoline now, than was the case in the early 1900s.

\section{Waves of History II: Motivations for Re-introduction, 1965-2011}

In a recent presentation, Mitsubishi dates three "waves" of modern interest in EVs (Wing, 2010). The first wave was in the 1970s, in response to the U.S. "Muskie Act of 1970", which dealt with tailpipe emission reductions. The second started in 1990 as a response to emerging concerns over global warming, and to California's Zero Emissions Vehicle (ZEV) regulation. The third was dated as starting in 2002 as a response to oil dependency. This section discusses these motivations for re-introduction of electric vehicles, along with the evolution of the technologies attempted.

In the 1890s the electric passenger car did not prove to be a viable competitor for personal transportation - even in urban areas. However, it is not true that electrified transportation failed. Quite the contrary - electrified subways and street railways were built in significant numbers in major urban areas in the 1890s and early 1900s (Middleton, 1974), sharply reducing the urban waste problem from both the horse and the iron horse. Horse manure and decaying horse carcasses were both significantly reduced. Smoke from steam powered street railways was not eliminated, but it was removed to more distant central generation stations. In later decades, gasoline buses and cars first helped in finally eliminating the horse, and eventually eliminated electrified urban transportation, in many cases contributing positively to reducing particulate emissions from power plants. Particulate emissions reduction efforts came first because this was an obvious pollutant, dirtying clothes and building facades. Only after the automobile became dominant and scientific discoveries about the deleterious effects of tetraethyl lead and ozone accumulated, did this less obvious pollution from the tailpipe of the passenger car become evident. 
A new reason for considering EVs is their absence of dependence on oil, now an import concern in both the U.S. and Europe. Fuel imports were not a concern in the U.S. in the early 1900s. In fact, oil discoveries in the U.S. clearly played a positive role in the adoption of the gasoline vehicle at that time. Soon after WWII, automakers in two nations without domestic oil resources produced EVs for a short while. Nissan mentions that its founding company offered an EV for a few years after WWII (Nissan, 2011). PSA also mentioned to this Annex that it had developed an EV in 1945. Otherwise, it appears that no post-WWII EVs were commercialized by major automakers until the 1990s, after several noteworthy developments in the late 1980s. However, EV research began earlier. Due to air pollution concerns that first became evident in California, EVs began to be investigated by automakers again in the 1960s.

In fact, the very success of the gasoline-fueled internal combustion ICE in the U.S., in one of the leading oil producing states at the time, contributed to the emergence of the second most populous city, Los Angeles, on the West Coast, facing Asia. That location later played strongly into interactions with Japan. Where New York - a state without oil resources had been developed at high density with considerable use of electricity for transport via a sophisticated subway and electrified commuter rail network, the early electric commuter system in Los Angeles was abandoned for the bus. Los Angeles thrived and grew rapidly, but the emissions of gasoline vehicles, trapped within a basin surrounded by mountains, led to unacceptable air pollution, in the form of ozone.

In the 1960s, California began studying the effect of gasoline vehicle related emissions of hydrocarbons and nitrogen oxides on ozone, finding that both were important contributors. Regulatory institutions were put into place and regulations were adopted, first to reduce hydrocarbon emissions from tanks that stored gasoline and other hydrocarbons, then from gasoline vehicles themselves. The emerging research and success in developing emissions reducing technology in California led to recognition nationwide that gasoline vehicle emissions would have to be reduced sharply if the nation was to continue to rely on the automobile as the foundation for its transportation. In 1970, the "Muskie Act", the Clean Air Act Amendments of 1970, was passed. Amending an original 1963 law, this law has recently been cited by both Toyota and Mitsubishi as a watershed event affecting their work on future powertrain technology for the automobile. Both Takehisa Yaegashi (revered within Toyota as 'the father of the hybrid') and Masatami Takimoto (Fairley, 2009) said that this Act was instrumental in causing Toyota's engineering department to begin reevaluating the powertrain for automobiles. Electric vehicles and hybrids were among the powertrains evaluated at the time. Takimoto dates Toyota's evaluation of "all kinds of hybrid systems" series, parallel, mild, full - from 1969. Since 1969 precedes the passage of the Muskie act, we presume that Toyota was tracking the events in California and Los Angeles and regarded these as potentially important for its long-term market development.

Mitsubishi also cited the Muskie Act of 1970, and mentioned their Delica EV (a passenger van) and Minica EV (a two door sedan) at that time (Wing, 2010). General Motors' recent placement of its "first" EV, in a historical timeline, was the 1966 Electrovan (Mathe, 2010). This date also precedes the Muskie act, suggesting that emerging air pollution concerns in CA were having an effect on GM as well. The date also opens the possibility that Toyota and Mitsubishi were partially responding to GM and California initiatives and the Muskie Act only reinforced the desire to investigate alternative methods for tailpipe emissions reduction. A recent timeline on the history of the electric car by America's Public Broadcasting system says that in 1966 
Congress introduces the earliest bills recommending use of electric vehicles as a means of reducing air pollution. A Gallup poll indicates that 33 million Americans are interested in electric vehicles.

The 1966 co-dating of GM's Electrovan and introduction of bills in Congress (introduction does not mean that the bill became law) and the Gallup poll suggests that tailpipe emissions concerns were already a significant U.S. national issue before 1970.

GM's timeline also shows one of the most successful low volume EVs ever, the 1972 Lunar Rover (Matthe, 2010). PSA reported to the IEA Annex that it had prototype electrified versions of the 17 and 104 models in 1972. These vehicles used lead acid batteries. BMW (Schamer, Lamp and Hockinger, 2010) dates its first EV at 1972, using lead acid and attaining a range of 30 miles. Their next BMW citation was 1987, based on the sodium sulfur battery chemistry, which had taken 20 years of development before being put into an automobile. These actions clearly predate the 1973-74 world oil price shock, subsequent 1974-75 collapse in automotive sales, and recession.

In May, preceding the October 1973 attacks on Israel by Egypt and Syria, and the subsequent Arab Oil Embargo that precipitated the oil price shock, Lee Iaccoca of Ford had solicited a long-term assessment of automotive powerplant options. The study solicitation award was made in Dec. of 1973. This study - "Should we have a new engine?" - was completed in August of 1975 by the solicitation winner, the Jet Propulsion Laboratory (Stephenson, 1975). The study concluded that it was clear that Brayton and Stirling engines should receive research funding as improvements were made to the internal combustion engine until these technologies could succeed. Electric vehicles and hybrids were regarded as undesirable (Lindsley, 2006). As the study progressed, Electric Vehicle Symposium Number 3 was held in 1974 in Washington DC. The Electric Auto Association (2005) considers the introduction of the two seat Sebring-Vanguard CityCar in Feb. (five months after the initiation of the Arab Oil Embargo) at the Symposium as a noteworthy event. The CitiCar had a top speed of $64 \mathrm{kph}$.

Despite the Jet Propulsion Laboratory's recommendation that research not be pursued on electric vehicles, the U.S. Public Braodcast System (PBS) (2009) indicated that, a year later, in 1976

Congress passes the Electric and Hybrid Vehicle Research, Development, and Demonstration Act. The law is intended to spur the development of new technologies including improved batteries, motors and other hybrid electric components.

Several electric vehicles - generally small and low volume - were produced worldwide in the 1970s (Anderson and Anderson, 2010), though none by large OEMs. These appear to have been supported and perhaps inspired by the high oil prices of the period. None are mentioned after 1983 (About.com, 2011, Public Broadcast System, 2009, Anderson and Anderson, 2010, Electric Auto Association, 2005). Variants of the CitiCar were produced until 1982, with total production about 4000 vehicles. Oil prices peaked in 1981, declined steadily until 1985, then dropped precipitously.

In 1985 the Swiss initiated the "Tour de Sol", a Swiss solar car race that was held every year until 1993, promoting development of solar technology. This was the first solar car race. Mercedes Benz sponsored the winning entry (Muntwyler, 2011). In 1987 the first World Solar Challenge race in Australia was run, over a distance of 1877 miles. General Motors sponsored the winning car in this race, the Sunraycer. Also in 1987, after a period of 15 years, BMW developed its second EV conversion vehicle, a 325 model with a sodium sulfur battery (Schamer, Lamp and Hockinger, 2010). 
In the United States, an unusually hot summer in 1988 was accompanied by a jump in average national ozone levels, after several consecutive years of decline. In 1988 Roger Smith of General Motors "agrees to fund research efforts to build a practical consumer electric car" (Public Broadcasting System, 2010). From 1988-1990, oil and gasoline prices once again rise significantly, though not as severely as in 1973-74 or 1978-81. Nevertheless, a U.S. recession follows. The Aerovironment company prototype arising from the 1988 agreement, the two seat lightweight aerodynamic electric sports car, the "Impact" is introduced at the Los Angeles auto show in 1990 and the California Air Resources Board passes its Zero Emissions Mandate, requiring 2\% of the state's sales of vehicles to consist of vehicles with zero tailpipe emissions in 1998, rising to $10 \%$ by 2003 .

Another influence was also emerging. In 1988 the United Nations established the Intergovernmental Panel on Climate Change (IPCC), and in 1990 the first Assessment Report of the Panel was released (IPCC.org). This report served as the basis for negotiating the 1992 United Nations Framework Convention on Climate Change (UNFCCC) in Brazil. In Europe and Japan, the significant emerging concern over global warming being codified by the United Nations also promised significant change to come in the those markets.

BMW developed an "E1" EV in 1991 using the sodium sulfur battery, and another EV based on the 325 model in 1992, now using the high temperature sodium nickel chloride (Zebra) battery. By 1993, Germany had set up field tests of 60 electric vehicles on Reugen Island. In 1992, Ford placed into service a fleet of 80 small vans - the ECOSTAR - in Europe and the U.S., using the Zebra battery.

Based on interviews conducted by the IEA HEV\&EV Implementing Agreement's "Lessons Learned" study, Japan and its automakers - who held a significant share of the California market - reacted strongly to the announcement of the GM Impact and the ZEV mandate. Throughout the 1990s, worldwide concern over GHGs began to emerge, along with agreements to develop greenhouse gas reduction strategies. In mid-decade, domestic pressure on automakers in Japan to meet previously agreed national fuel efficiency goals and to show significant progress before the 1997 Kyoto Japan meeting on climate change led to acceleration of Toyota efforts to implement electric drive technology to improve fuel efficiency.

Early in his administration, Al Gore, U.S. Vice President, began promoting research on very high efficiency vehicles. Congress funded this multi-agency, multi-manufacturer "Partnership for a New Generation of Vehicles (PNGV)" research in 1993, but would not support U.S. participation in international agreements to reduce GHGs. Hybrid powertrains were among the technologies chosen to enable very significant improvements in fuel efficiency, but significant research on electric vehicles was not a part of the program due to probable functional limitations including range, speed of "re-fueling", package space and infrastructure concerns. Battery research was supported, but not vehicle research.

Toyota responded to pressures from its government, California's government, and the U.S. research program supporting three of its competitors with an aggressive effort to develop a much more fuel efficient mass market vehicle that would allow Japanese consumers to move up to a larger, but considerably more fuel efficient vehicle than their leading world seller, the Toyota Corolla. This vehicle was named the Prius, which in Latin means "to go before". The first generation of the Prius was only sold in Japan. After a degree of reliability was assured, the Prius was sold in the U.S. In each generation it became larger, faster, and more fuel efficient. It moved from an initial U.S. size classification of compact car up into the midsize category in 2004. 
In the late 1990s electric vehicles were produced and evaluated by Toyota in both Japan and California, but were abandoned - for reasons similar to those given by PNGV for not focusing on electric vehicles.

After the oil price shock of 1988-90, oil prices had been relatively stable for nearly a decade. Concerns over availability of oil had subsided. Test fleets of EVs were placed in service in California in the late 1990s. Volumes produced by each manufacturer were generally less than 1000. Automakers decided to oppose the introduction of EVs in other states and legally opposed any expansion of California's ZEV mandate to other states in the U.S. At the turn of the century, production was halted and cars were reclaimed by some manufacturers. All but Nissan used Nickel Metal Hydride or lead acid batteries. Nissan produced a few EVs using lithium ion batteries, now regarded as very promising. Among the participating manufacturers, Nissan was under the greatest financial stress. It too halted EV production. Gasoline vehicles had become far more efficient and far cleaner. Once again, improvements in the gasoline vehicle held the electric vehicle back.

Even an oil price increase from 1998 to 2000 did not revive interest in EVs by automakers and Congress. The PNGV project had led to production of a fuel cell hybrid by GM. This was also a zero tailpipe emissions vehicle which did not have the range limitations of an EV. California, major world automakers and oil companies agreed to a Fuel Cell Partnership to develop hydrogen fuel cell vehicles. The ZEV regulations were restructured. For several years, attention turned to fuel cell vehicles.

During this period, the lithium ion battery chemistry was completely supplanting $\mathrm{NiMH}$ in consumer electronic applications. The price and performance of cells with this chemistry were rapidly improving. Theory said that this chemistry could realize greater energy and power density than NiMH (Kalheimer et al, 2007). This was being proven in practice.

In 2003, four years after California and major automakers had shifted attention to fuel cells, Tesla motors was formed with the intention of producing a high performance two seat electric sports car. In a 2006 presentation to the California Air Resources Board, Tesla compared its coming roadster to high performance sports cars selling for prices of $\$ 100,000$ to half a million and more (Eberhard, 2005). A key point of the presentation focused on delivery of miles of service per unit of original feedstock by the roadster in comparison to conventional high performance vehicles powered by internal combustion engines. Perhaps the key slide was the one comparing miles of service from wind, solar, hydroelectric and geothermal power via electricity vs. hydrogen. Although it must be remembered that the vehicles compared differed significantly in terms of range, the Tesla comparison dramatically favored the electric pathway.

Another slide highlighted the side effect of greater efficiency - less use of land resources. It may not be obvious, but this point is one that goes beyond computation of oil saving, tailpipe emissions reduction, and GHG reduction. For both an electricity-to-electric-vehicle pathway and an electricity-to-hydrogen fuel cell vehicle pathway, the oil savings, tailpipe emissions reductions, and GHG reductions will be about equal per mile. For tailpipe emissions and GHG reductions, since the pathways have nearly zero emissions, comparisons of pathways with different numbers of miles of operation will look the same if expressed on a percentage basis - about $100 \%$ reduction. However, the pathways may differ considerably in another respect, even when compared on the basis of percentage change. The fourth respect is "sustainability" - the more miles of service from a given feedstock, the more sustainable the resource base.

Distilled, what Tesla was arguing is that if the vision is a sustainable future for transportation based on use of renewable fuels, Tesla had identified a market niche where 
that transportation can be provided at lower cost with greater levels of service than hydrogen (or gasoline or biomass). Looked at another way, the argument was that, for any single renewable fuel examined, more miles of service can be provided by electric drive in modest range electric vehicles than if fuel cell hydrogen vehicles were used for the same purpose. Although it may be true that an electric vehicle cannot be anticipated to be a universal replacement for gasoline, due to its range and refueling time limitations, it does now have a widespread refueling infrastructure available and it can be started in market niches at much lower cost than fuel cell vehicles.

In the following year at the $23^{\text {rd }}$ Electric Vehicle Symposium in Anaheim CA, a paper was presented that showed that this general argument also holds true for fossil fuels competing with oil, most notably for natural gas used to generate electricity in combined cycle power plants (Gaines et al, 2008). It appears that a proper generalization is that once a fossil or biomass fuel feedstock is gasified, it is more efficient to use the gas to generate electricity and provide electric drive than to turn that gas into a liquid for use in internal combustion engines, or to convert it into clean hydrogen for use in a fuel cell vehicle. For wind, solar, hydro and geothermal, the lesson is to never produce a gas (hydrogen), use the electricity directly. The critical caveat remains that this applies to probable niche vehicles with modest amounts of electric range compared to typical gasoline and fuel cell vehicles.

Lesson: for any single fuel/feedstock pathway, with technologies plausible in the near term, more miles of service can be provided via that feedstock by electric drive in modest range electric vehicles than if fuel cell hydrogen vehicles (or liquid fuels from that feedstock in ICEs) were used for the same purpose.

Tesla, selling its high performance roadster at a cost that undercuts many exotic sports cars, has since sold over 1200 of the roadsters. GM produced less EV1s and did not sell any. It only leased them. Though Tesla has yet to sell as many roadsters as 1970s CitiCars sold, it undoubtedly sold far more kWh of battery pack capacity and far more dollars of value of EVs by early 2011, then being the U.S. leader in these terms. Tesla production took advantage of a degree of pre-existing volume production for components. The roadster was produced by re-engineering a Lotus Elise body and frame. As of 2003, the Elise had been in production since 1995. 17000 had been produced (Conceptcars.com., 2003). Lithium ion cells used in the battery pack of the Tesla were standard commercial cells that had been perfected via several years of production for consumer electronic applications.

Price remains an issue. The Lotus Elise sells at a price of about $\$ 50,000$, while the Tesla Roadster sells at a price of over $\$ 100,000$. The Tesla Roadster accelerates to $60 \mathrm{mph}$ faster than the Elise [3.7 (Tesla, 2011) vs. 4.4 (Zero to Sixty Times, 2011)], but has a lower top speed (125 mph vs. $150 \mathrm{mph}$ ). Its "acceleration feel" to an owner may be superior to the Elise because of the high initial torque available for start-up acceleration.

As Tesla developed their roadster for the performance market niche, oil prices continued a steady rise, reaching levels in 2008 that caused a widespread international collapse in automobile sales. Due to the encouraging long-run environmental and sustainability arguments on behalf of electric drive relative to hydrogen fuel cells, governments began to shift funds and commitments toward electric drive in plug-in hybrids and electric vehicles. Thanks in part to subsidies and to oil prices through 2008, the world market share of hybrids rose steadily through 2009. First the U.S. adopted subsidies, then Japan.

The technical possibility to convert a 2004 generation Prius to a plug in hybrid was demonstrated by the organization CalCars, using lead acid batteries. Multiple companies then produced prototypes making use of lithium ion battery packs. In 2008 the battery 
manufacturer A123 purchased the company Hymotion, then safety certified and produced a $5 \mathrm{kWh}$ lithium iron phosphate battery pack Prius plug-in conversion for $\$ 10,000$. U.S. Government testing of a fleet of plug-in Prius vehicles is demonstrating some of their strengths and weaknesses.

For European high performance vehicle manufacturers, electric drive offers the opportunity to meet ever tightening carbon dioxide emissions regulations while still selling vehicles with the historical level of performance customers expect. Several European OEM's that focus on high performance are now developing extended range electric vehicles conceptually similar to the Chevrolet Volt, but with considerably higher power.

To overcome the battery pack cost problems of the Tesla, assuming middle class customers, the Leaf uses a battery pack whose much larger, next generation "prismatic" cells are designed for automotive use. The new battery cell and pack redesign requires very high volume production to allow moderately competitive costs. Battery research is progressing steadily, with promise of favorable lifetime cost reductions for selected customers of plug-in vehicles using coming generations of lithium-ion-based automotive batteries. Few OEMs expect plug-in vehicles to become dominant technologies in the next decade or two. However, many now expect them to succeed in large enough numbers, at low enough costs, that the risks of not producing them are greater than the risks of producing them. Many are choosing to pursue a portfolio of electric drive technologies, including hybrids, plug-in hybrids, and electric vehicles.

The desire by both existing and new automakers to develop and produce vehicles that will sharply reduce oil use has become powerful. Due to the emergence of concerns over greenhouse gases, the desire for minimum emissions - close to zero - has shifted from just the tailpipe to the entire fuel delivery pathway. To the detriment of the hydrogen fuel cell option, this shift in thinking has changed the perspective on use of both renewable and fossil feedstocks for the provision of vehicle miles of service. Electricity - properly implemented - appears to be the best technically feasible near term alternative for enhancement of sustainability of transportation in personal light duty vehicles. Unfortunately, due to the cost of electric drive, less sustainable alternatives will continue to hold the majority of the market for the foreseeable future.

\section{What is different this time, what is not?}

At this time the automobile industry is well established, with very large manufacturers. One, Nissan is planning for very high volume EV production in a short period of time. Based on the one comparison made here, the additional initial cost of electric vehicles, on a percentage basis, does not appear likely to be much different than in the 1920s. Thus, the need to heavily utilize the vehicle in order to pay back the added costs of purchase remains very important (Kley, Dallinger and Weitschel, 2010; Santini et al, 2011). Accordingly, the kinds of financially attractive market niches for electric vehicles today are probably very similar to those in the early 1900s. However, the extent of these markets is now considerably greater. The competition now is only with the internal combustion engine using refined petroleum products, not the horse. The share of population in suburbs in the U.S. is also far greater, as is the general affluence of the population.

The performance of the Nissan Leaf electric remains to be evaluated by auto magazines and the U.S. Department of Energy, but initial information indicates that it will be competitive or better than gasoline vehicles of the same size with base engines (My Nissan Leaf, 2011; 
Autoblog, 2011). It is clear that this generation of electric vehicles using lithium ion battery packs (Nissan Leaf, BMW Mini-E, Tesla Roadster) has significantly better acceleration performance than comparably sized vehicles using nickel metal hydride battery packs in the 1990s (Idaho National Laboratory, 1996a\&b, 1999a\&b, 2009, My Nissan Leaf, 2011), and higher top speed. A Nissan auto show presentation indicates that the Leaf has the fastest 0 $48 \mathrm{~km} / \mathrm{h}$ time of any Nissan vehicle sold (Nissan, 2011). Thus, the response of consumers in everyday urban and suburban driving, on neighborhood, feeder, and arterial roads with stop signs and stop lights, and speed limits of $88 \mathrm{kph}$ and less may be very favorable.

Based on interviews of those who tested the BMW Mini-E, the range of today's electric vehicle using lithium ion batteries is adequate for most needs, but consumers want a charging infrastructure, apparently to be able to use the electric on days when driving distance exceeds the range (Presse Box, 2011). Unless consumers have a strong preference for the EV for its rapid initial acceleration capabilities, financial calculations imply that driving less kilometers per day than the range of the electric vehicle will not be financially desirable in the United States at current and somewhat higher gasoline prices (Santini et al, 2011). Recent evaluations for Europe indicate that fuel taxes (much higher than in the U.S.) will cause EVs and PHEVs to be financially attractive there. However, with "untaxed numbers no PHEV or EV was selected for any battery price." (Kley, Dallinger and Weitschel, 2010). As has been discussed, Europeans drive less kilometers per day on average than in the U.S., and at lower average speed, which tends to offset the EV favoring effects of higher fuel prices there. Further, expectations for top speed in some nations with limited access highways allowing much higher speed than in the U.S. may work against these EVs, which continue to have somewhat limited top speed relative to competing gasoline vehicles. For metropolitan area driving on limited access highways, it appears that coming EVs will have adequate top speed (135-145 kph). In most U.S. urban areas speed limits on such highways are $88 \mathrm{kph}$, though actual speed often significantly exceeds the limit. For inter-city travel on U.S. Interstates, speed limits vary, but consistently range from 104 to $120 \mathrm{kph}$, with higher speeds not unusual. Modern full function EVs using lithium ion battery packs will be capable of going fast enough on U.S. Interstates, but the effects on range will be a significant issue.

Many households now own a fleet of vehicles, so it is now possible for many middle income households to mix a gasoline and electric vehicle in a two car fleet, optimizing the use of the pair of vehicles. Electric service is available in almost every dwelling, though garage and carport space is not. The proportion of households living in urban and suburban areas is far greater than it was in the early 1900s. While the capability of driving off-road and on dirt roads remains a selling point for some consumers today, it is no longer a need of the majority of customers for motor vehicles, as it was in the U.S. in the early 1900s.

Culturally, the car is less an "adventure machine" than in the early 1900s. Aircraft are often used for trips out of town, rather than the highway vehicle. Those who are very affluent are likely to use air travel to a significant degree. From a financial viability perspective this will actually hurt the EV for this customer base, because the EV will be used less days per year than by less affluent consumers who do not fly as often.

An adequate road network exists today, with very great functional flexibility in choice of destinations. As in the 1900s, there remains a need for reliable low rolling resistance tires particularly for EVs. EVs and "extended range electric vehicles" (EREVs) are consistently using lower rolling resistance tires than are gasoline vehicles. 
For the U.S., the establishment of a petroleum products delivery infrastructure before the advent of the gasoline car was an advantage, which was reinforced by the discovery of abundant oil supplies. Today, the U.S. has built a considerable number of efficient combined cycle natural gas powerplants to serve air conditioning demands, creating a high summertime peak and a deep and wide summertime overnight trough. In their recent assessment of the use of electric power by plausible, but optimistic numbers of plug-in hybrids, Argonne National Laboratory scientists (Elgowainy et al, 2010) estimated that the vast majority of power would be provided by already existing combined cycle natural gas powerplants. In the meantime, significant new resources of shale gas have become available in the U.S. (and probably elsewhere in the world) as a result of developments in drilling technology (Energy Information Administration, 2011). Thus, today the plug-in electric vehicle also has the benefit of a widely available existing electric delivery infrastructure whose electricity can be generated by an abundant resource, natural gas. The petroleum delivery infrastructure today appears to be at risk of dependence on expensive oil resources whose production may be reaching a worldwide plateau, while worldwide demand continues to rise.

Environmental motivations by the affluent today are far different than in the early 1900s. Due to dramatic improvements in the gasoline vehicle, reduction of local noise and smell are much less a concern today, though they remain a factor. Nitrogen oxides and particulate emissions of the diesel have become a concern in Europe, where diesel emissions regulation had been more lax than for gasoline. However, the leading new environmental concern for many affluent vehicle consumers and many national governments is global warming. The perception of the environment has changed. Escape from this environmental problem by moving to a different location (such as suburbanization in the U.S. in part to escape dirty industrial core cities) is no longer a possibility. Thus, changing the choice of technology to one with less global warming effect - rather than moving away from pollution - is a higher priority for those affluent consumers who wish to contribute to mitigating this problem. Plug-in electric vehicles are seen as enabling technology that can enhance the technical and economic feasibility of electrical generation with wind and solar power, two ultimate clean sources of such power. Combined cycle natural gas powerplants, relatively clean among fossil fueled power plants, have technical flexibility to vary load rapidly, creating the possibility of synergism with fluctuating wind and solar.

Thus, as in the early 1900s, the perception of the electric vehicle as a clean environmentally friendly vehicle remains important, though with a significant change in perspective.

Neither the U.S., nor Europe is growing as rapidly as in the early 1900s. New single family dwelling units, which can most inexpensively be designed to allow for plug-in vehicle charging - retrofit costs for existing units being much higher - are certainly not being built at a rate proportional to the growth in the early 1900s, so neighborhood and dwelling unit charging infrastructure costs will be relatively higher.

Since solar and wind resources are consistently exploited locally, these ultimately clean resources also have the benefit of reducing oil imports for the U.S. and Europe, which is a much greater concern than it was in the early 1900s. Similarly, shale gas also appears to offer many nations an enhanced opportunity to substitute another domestically produced transportation energy source for imported oil (Energy Information Agency, 2011).

The final key difference is that the hybrid electric vehicle has established a relatively steadily increasing market niche since the 1990s, while this technology was unsuccessful relative to the electric vehicle in the early 1900s. For the Kreiger hybrid of a few years after 1900, the 
battery pack accounted for $25 \%$ of the vehicle mass (Mom, p. 126); for the 2004 Prius, the pack accounted for $3.5 \%$ of vehicle mass. Obviously, there are many other critical developments that have enabled hybrids to succeed, but minimizing pack size needed is certainly an important one.

It is being demonstrated that a plug-in adaptation of a hybrid can be developed, and that "electric vehicles" can be modified to include an engine and generator and use gasoline to extend the range. Engineering and cost evaluations of several different configurations of plug-in hybrid and range extender electric vehicles have been conducted (Kromer and Heywood, 2007; Passier et al, 2007; Moawad et al, 2009; Shiau et al, 2009; Axsen, Kurani and Burke, 2010, Kley Dallinger, and Weitschel 2010; Propfe and de Tena, 2010; Santini et al, 2011). The conclusions of those studies that have examined cost is that the plug-in hybrid with $4-8 \mathrm{kWh}$ of battery pack storage will be more cost effective than the extended range electric vehicle with $12-16 \mathrm{kWh}$ of battery pack, which in turn will be more cost effective than the electric vehicle with $160-320 \mathrm{~km}$ of range and $24 \mathrm{kWh}$ or more of battery pack. As battery costs drop, the financial viability of the vehicles with more and more battery pack capacity increases (Shiau et al, 2009; Kley, Dallinger and Weitschel, 2010; Propfe and de Tena, 2010). However, the decline in battery pack costs does not eliminate the desirability of plug-in hybrids and make electric vehicles win; it makes a more diverse mix of plug-in vehicles desirable. At anticipated 2020 battery pack costs, and historical oil prices, unsubsidized 4-5 passenger personal light duty electric vehicles are not estimated to be financially attractive for the vast majority of consumers.

Thus, the engineering cost evaluations imply that the first step in the next wave of electrification of the motor vehicle is adaptation of the hybrid - further gradual electrification of the conventional powertrain, not a jump to an emphasis on pure electric drive. If electrics are to be implemented, it can be expected that choice of the best market niches will be critical - as it was in the early 1900s - and initial market shares will be small.

\section{Acknowledgments}

The author would like to gratefully acknowledge the sponsorship of David Howell, Team Leader, Hybrid and Electric Systems, Office of Vehicle Technology, U.S. Department of Energy. This paper is the author's extension of an assignment by the International Energy Agency Hybrid and Electric Vehicle Implementing Agreement's Annex XIV multi-country study "Market Deployment of Hybrid \& Electric Vehicles: Lessons Learned" to examine the historical determinants of the multiple waves of effort to develop and deploy personal use highway vehicles with electric drive since WWII. The author was inspired to extend this assignment back to 1895 due to the rich amount of technical detail and extremely insightful interpretation in Gijs Mom's book “The Electric Vehicle: Technology Expectations in the Automobile Age", originally published in Dutch, and translated into English in 2004. The interpretations in this analysis are those of the author and not the sponsoring organizations. Special thanks are due to the "Operating Agent" and members of the Annex XV study team, Tom Turrentine (OA, U.S.), Sigrid Kleindienst Muntwyler (Switzerland), Kanehira Maruo (Sweden) and Bjoern Budde (Austria), though none are to be held responsible for my interpretations. Thanks are also due to the many participants in the workshops of the Annex, too numerous to list here. Information on the progress of Annex XIV over its operations period can be found in the Annual Reports of the Hybrid and Electric Vehicle Implementing Agreement (http://www.ieahev.org/publications/index.html). 


\section{References}

About.com. The History of Electric Vehicles. http://inventors.about.com/library/weekly/aacarselectricla.htm. Accessed April 7, 2011.

Anderson, C.D. and J. Anderson (2010) Electric and Hybrid Cars: A History 2nd Ed. MacFarland and Company. NC

Autoblog (2011). http://www.autoblog.com/2010/10/22/unofficial-nissan-leaf-does-0-60mph-in-7-seconds-tops-out-at/. Accessed April 7.

Axsen, J. K. Kurani and A. Burke. (2011). Are batteries ready for plug-in hybrid buyers? Paper 10-0732, presented at the 89th Annual Meeting of the Transportation Research Board, Washington, DC. (Jan. 9-13)

Berretta, R. (2009). Daimler AG Fuel Cell Vehicle Technology for Passenger Vehicles. California Air Resources Board ZEV Symposium, Sacramento CA. Sept. 21.

Conceptcars.com. (2003). Lotus Announce Elise for USA. http://www.conceptcarz.com/vehicle/z6643/Lotus-Elise.aspx accessed Oct. 10, 2010.

Eberhard, M. (2006). Tesla Motors. Presented at the California Air Resources Board ZEV Symposium, Sacramento, CA. Sept. 26.

Electric Auto Association (2005). Electric Vehicle History (May). http://www.eaaev.org/Flyers/eaaflyer-evhistory.pdf

Electrification Coalition (2009). Electrification Roadmap http:/ / www.electrificationcoalition.org/electrification-roadmap.php. Nov.

Elgowainy et al, (2010). Well-to-Wheels Analysis of Energy Use and Greenhouse Gas Emissions of Plug-in Hybrid Electric Vehicles. Argonne National Laboratory Report ANL/ESD/10-1. Argonne, IL. June.

Energy Information Agency (2011). World Shale Gas Resources: An Initial Assessment of 14 Regions Outside the United States. http://www.eia.doe.gov/analysis/studies/worldshalegas/. April 5.

Fairley, P. (2009). Toyota's Secret: The Clean Air Act of 1970 http://spectrum.ieee.org/energywise/energy/renewables/toyotas_secret_the_cle an_air_a.html. accessed March 16.

Gaines, L., et al. (2008). Sorting Through the Many Total-Energy-Cycle Pathways Possible with Early Plug-In Hybrids. World Electric Vehicle Journal, 2 (1): 1 74-96.

Generations of GM History: Heritage Center (2011). http://history.gmheritagecenter.com/wiki/index.php/1904_Curved_Dash_Owne r\%E2\%80\%99s_Manual. accessed April 7, 2011.

Idaho National Laboratory (1996a). Toyota RAV4EV. http:/ / avt.inel.gov/pdf/fsev/eva/toyrav96.pdf. accessed April 7.

Idaho National Laboratory (1996b). Toyota RAV4EV w/NiMH. http:/ / avt.inel.gov/pdf/fsev/eva/toyrav98.pdf. accessed April 7.

Idaho National Laboratory (1999a). 1999 General Motors EV1 w/NiMH. http://www1.eere.energy.gov/vehiclesandfuels/avta/pdfs/fsev/eva_results/ev1 _eva.pdf. accessed April 7.

Idaho National Laboratory (1999b). 1999 Ford Th!nk Urban Electric Vehicle. http://avt.inel.gov/pdf/uev/thinkcityueva.pdf. accessed April 7. 
Idaho National Laboratory (2009). BMW Motors 2009 Mini E. http:/ /avt.inel.gov/pdf/uev/fact2009bmwmini.pdf. accessed April 7.

Kalheimer F. et al (2007). Status and Prospects for Zero Emissions Vehicle Technology: Report of the ARB Independent Expert Panel 2007. Prepared for the State of California Air Resources Board.

Kley, F., D. Dallinger, and M. Weitschel (2010). Optimizing the charge profile - considering user's driving profiles. Working Paper Sustainability and Innovation No. S. 6/2010. Fraunhofer ISI, Germany.

Kromer, M. A. and J. B. Heywood (2007). Electric Powertrains: Opportunities and Challenges in the U.S. Light-Duty Vehicle Fleet, Laboratory for energy and the environment publication No. LFEE 2007-03 RP. Massachusetts Institute of Technology, Cambridge MA. May.

Lindsley, E.F. (2006) Lifting the Hood on Future Car Engines. Popular Science, 208 (4) pp. 82-86; 153. April.

Loeb, A.P. (1995). The Birth of the Kettering Doctrine: Fordism, Sloanism and the Discovery of Tetraethyl Lead. Business and Economic History 24 (1) pp. 72-87.

Mahajan, V. and R.A. Peterson (1985). Models for innovation diffusion. Sage Publications. Beverly Hills CA.

Matthe, R. (2010). Vehicle integration of the Chevrolet Volt Battery. Advanced Automotive Battery Conference, Orlando, FL. May 17-21.

Melaina, M.W. (2007). Turn of the century refueling: A review of innovations in early gasoline refueling methods and analogies for hydrogen. Energy Policy 35 pp. 4919-4934

Middleton, W.D. (1974). When the Steam Railroads Electrified, Kalmbach Publishing Co. Milwaukee WI.

Mom, G. (2004). The Electric Vehicle: Technology and Expectations in the Automobile Age. The Johns Hopkins University Press, Baltimore.

Moawad et al (2009). Impact of Real World Drive Cycles on PHEV Fuel Efficiency and Cost for Different Powertrain and Battery Characteristics. The 24th World Battery, Hybrid and Fuel Cell Electric Vehicle Symposium and Exhibition (EVS-25). Stavenger, Norway May 13-16.

Muntwyler, U. (2011). EV and PV: a winning combination has its 25 years anniversary. International Advanced Mobility Forum, Geneva. March 8-9.

Naul, G.M., ed. (1978). The Specification Book for U.S. Cars, 1920-29. Motorbooks International, Osceola, Wis.

Naul, G.M., ed. (1980). The Specification Book for U.S. Cars, 1930-69, Motorbooks International, Osceola, Wis.

Nissan Official U.S. Media Newsroom (2011). Nissan's pursuit for zero emissions mobility: the unplugged story.

http:/ /www.nissannews.com/pressrelease/790/1/nissan's-pursuit-zero-emissionmobility-unplugged-story. accessed April 7.

Passier, G. et al. (2007). Status Overview of Hybrid and Electric Vehicle Technology (2007): Final Report Phase III, Annex VII, IA-HEV, International Energy Agency, Paris, France Dec.

Presse Box (2011). Mini E UK Field Trial Switches Off. http://www.pressebox.com/pressreleases/bmw-ag-0/boxid/412690. accessed April 7. 
Pressnell, J. (1992). Great Cars of the World. PRION - Multimedia Books Ltd.

Propfe, B. and D. L. de Tena (2010). Perspectives of electric vehicles: customer suitability and renewable energy integration. Proceedings of the 25th World Battery, Hybrid and Fuel Cell Electric Vehicle Symposium and Exhibition (EVS-25)., Shenzhen, China. Nov. 5-9.

Public Broadcast System (PBS) (2009). Timeline: History of the Electric Car. Oct. 30. http://www.pbs.org/now/shows/223/electric-car-timeline.html

Santini, D.J., K.G. Gallagher, and A.P. Nelson (2010). Modeling of Manufacturing Costs of Lithium-Ion Batteries for HEVs, PHEVs, and EVs. The 25th World Battery, Hybrid and Fuel Cell Electric Vehicle Symposium and Exhibition (EVS-25). Shenzhen China. Nov. 5-9.

Santini, D.J. (2010). Highway Vehicle Electric Drive in the United States: 2009 Status and Issues. Argonne National Laboratory Report ANL/ESD 10-9. Argonne, IL.

Santini, D.J. et al (2011). Where Are the Market Niches for Electric Drive Passenger Cars? Paper no. 11-3733, 90th Annual Meeting of the Transportation Research Board Washington, D.C. January 23-27.

Satyapal, S. and Aceves, S (2009). Overview of Hydrogen and Fuel Cell Activities. California Air Resources Board ZEV Symposium, Sacramento CA. Sept. 21.

Schamer, S., P. Lamp, and E. Hockinger (2010). Development of Hybrid Vehicles at BMW and their Energy Storage Solutions. Advanced Automotive Battery Conference, Orlando, FL. May 17-21.

Schiau et al (2009). Impact of battery weight and charging patterns on the economic and environmental benefits of plug-in hybrid electric vehicles. Energy Policy 37. pp. 26532663.

Siry, D. (2008). Mythbusters Part 2: The Tesla Roadster is not a Converted Lotus Elise http:/ / www.teslamotors.com/blog/mythbusters-part-2-tesla-roadster-notconverted-lotus-elise. accessed March 3.

Stephenson, R.R. (1975). Should We Have a New Engine? An Automobile Power Systems Evaluation. Vols. 1 and 2. Jet Propulsion Laboratory Report JPL SP43-17, V I\&II. Pasadena, CA.

Suckow, T. (2009). Hyundai Fuel Cell Vehicles. California Air Resources Board ZEV Symposium, Sacramento CA. Sept. 21.

Sulzberger, C. (2004). An Early Road Warrior: Electric Vehicles in the Early Years of the Automobile. IEEE Power Engineering Society. May.

http://www.ieee.org/organizations/pes/public/2004/may/peshistory.html

Tesla (2011). http:/ / www.teslamotors.com/roadster. accessed May 19.

U.S. Department of Commerce. 1975. Historical Statistics of the United States: Colonial Times to 1970. Washington DC: GPO.

Vivian, D. (1994). Encyclopedia of American Cars. Brampton Books.

Vyas, A., D. Santini, and L. Johnson (2009). Plug-In Hybrid Electric Vehicles' Potential for Petroleum Use Reduction: Issues Involved in Developing Reliable Estimates. Transportation Research Record: Journal of the Transportation Research Board No. 2139. Transportation Research Board of the National Academies, Washington, DC, pp. 55-63.

Wikipedia (2011). War of Currents. http://en.wikipedia.org/wiki/War_of_Currents. accessed April 7, 2011. 
Wing, G. (2010). Mitsubishi Motors i-MiEV Fleet Test Experience. Presentation at the $10^{\text {th }}$ International Advanced Automotive Battery Conference, Orlando, FL. May 19-21.

Yokoyama, T. (2009). Progress and Challenges for Toyota's Fuel Cell Vehicle Development. California Air Resources Board ZEV Symposium, Sacramento CA. Sept. 21.

Zero to Sixty Times (2011). http:/ / www.zeroto60times.com/. accessed April 7. 


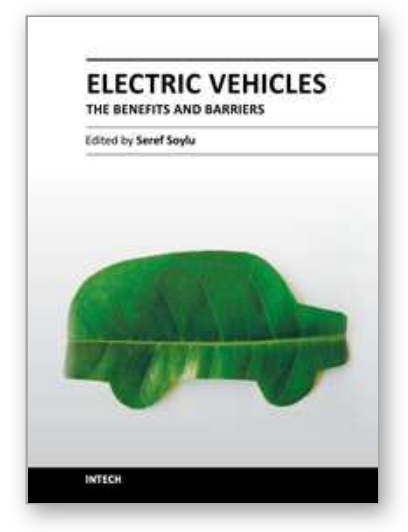

\author{
Electric Vehicles â€“" The Benefits and Barriers \\ Edited by Dr. Seref Soylu
}

ISBN 978-953-307-287-6

Hard cover, 240 pages

Publisher InTech

Published online 06, September, 2011

Published in print edition September, 2011

In this book, theoretical basis and design guidelines for electric vehicles have been emphasized chapter by chapter with valuable contribution of many researchers who work on both technical and regulatory sides of the field. Multidisciplinary research results from electrical engineering, chemical engineering and mechanical engineering were examined and merged together to make this book a guide for industry, academia and policy maker.

\title{
How to reference
}

In order to correctly reference this scholarly work, feel free to copy and paste the following:

D. J. Santini (2011). Electric Vehicle Waves of History: Lessons Learned about Market Deployment of Electric Vehicles, Electric Vehicles â€" The Benefits and Barriers, Dr. Seref Soylu (Ed.), ISBN: 978-953-307-287-6, InTech, Available from: http://www.intechopen.com/books/electric-vehicles-the-benefits-and-barriers/plug-inelectric-vehicles-a-century-later-historical-lessons-on-what-is-different-what-is-not-

\section{INTECH}

open science | open minds

\section{InTech Europe}

University Campus STeP Ri

Slavka Krautzeka 83/A

51000 Rijeka, Croatia

Phone: +385 (51) 770447

Fax: +385 (51) 686166

www.intechopen.com

\section{InTech China}

Unit 405, Office Block, Hotel Equatorial Shanghai

No.65, Yan An Road (West), Shanghai, 200040, China

中国上海市延安西路65号上海国际贵都大饭店办公楼 405 单元

Phone: +86-21-62489820

Fax: $+86-21-62489821$ 
(C) 2011 The Author(s). Licensee IntechOpen. This chapter is distributed under the terms of the Creative Commons Attribution-NonCommercialShareAlike-3.0 License, which permits use, distribution and reproduction for non-commercial purposes, provided the original is properly cited and derivative works building on this content are distributed under the same license. 